\title{
EDITORIAL
}

\section{A Formação da Enfermeira em Questão}

O modelo econômico brasileiro, excludente e concentrador de renda, que resultou numa sociedade caracterizada por profundas desigualdades sociais, não só quanto às condições de vida e saúde, como também quanto ao acesso a bens e serviços, coloca o desafio da construção de um novo modelo de atenção, que leve em conta o perfil epidemiológico da população e responda a este "apartheid" social.

Nesse contexto, coloca-se a questão do perfil das recursos humanos que deverão atender às demandas d o Setor Saúde, na perspectiva da reorientação do sistema, levando-se em consideração a pouca aderência do aparelho formador à realidade de saúde da população brasileira.

A nível da graduação, tem sido enfatizada, em diversos foruns de discussão e documentos, a inadequação dos atuais currículos das profissões da saúde. No caso da enfermagem, o processo de reformulação curricular, coordenado pela $A B E n$ e resultante de ampla discussão da categoria, encontra-se em uma etapa decisiva, dependendo do parecer do CFE.

A concepção do currículo tem sido mais freqüentemente interpretada como relação de matériasdisciplinas, dispostas em uma determinada seqüência, a serem cumpridas em um determinado tempo. Tal concepção tem resultado em reformas curriculares que não incorporam o processo ensino/aprendizagem, e conseqüentemente, não impactam significativamente no perfil do profissional graduado.

A atual estrutura curricular da área da saúde está centrada na dicotomia teoria/prática, ciclo básico/ciclo profissionalizante, ocorrendo o contato do aluno com o mundo do trabalho muito tardiamente. Conseqüentemente, o processo de trabalho em saúde não se constitui no eixo integrador do currículo, e o aluno apreende a realidade apenas através da ótica da profissão na qual está sendo formado, quando a realidade do mundo do trabalho exige uma prática multiprofissional.

Os contatos com o trabalho serão efetivados através do "currículo paralelo", seja por iniciativa do aluno, seja através de projetos de extensão, vinculados a determinadas disciplinas ou departamentos, mas geralmente descolados do currículo formal. 
A preocupação central no processo de formação está voltada para o domínio de habilidades técnicas (quanto mais densidade tecnológica, mais valorizadas), com pouca ênfase no desenvolvimento da capacidade crítica para a apreensão da realidade.

As características do alunado como procedência escolar, gênero, percepção e motivos de escolha da profissão, geralmente não são levados em consideração. Em síntese, implementa-se um currículo "ideal" para um aluno "idealizado".

A formação profissional inclui, além da definição de uma grade curricular, de uma opção de natureza ética: que compromisso está sendo estabelecido? Com todos ou com um grupo privilegiado? Estamos formando enfermeiras para quê? Para atender a quem?

Ao publicar um documento encaminhado pela ABEn ao Conselho Federal de Educação e artigos relacionados ao processo de formação da enfermeira, este número da REBEn não só reafirma a posição da entidade, mas propicia um avanço da discussão. A questão do ensino de enfermagem em qualquer nível, é restrita ao âmbito das universidades, escolas docentes e discentes. É uma questão que se explicita no cotidiano da prática profissional. É necessário assumí-la como um compromisso ético perante a sociedade. 